\title{
ORGANIZACJE KOOPERACYJNE JAKO WSPÓLNOTA CELU
}

\section{Abstract \\ Colaborative spaces as a community of purpose}

The role of values in the organizations has been the subject of an increasing amount of scientific attention. This paper describes values of collaborative spaces members intermediating in social exchange. The main research objective was to explore the organizational goals of these organizations and to reconstruct on this basis their aspirations and values to describe them as a community of purpose. Research method used is content analysis, which has been based on legal documents - statutes of non-governmental organizations working as collaborative spaces - Makerspaces, Hackerspaces and Fab Labs operating in Poland most often in the form of legal associations and foundations. The foundings provide a basis for further exploration of organizational phenomena occurring in cooperative organizations.

Keywords: collaborative spaces, values, organizational objectives, communities of purpose

\section{Streszczenie}

W artykule podjęto zagadnienie wartości cenionych przez społeczności wytwórców - członków organizacji kooperacyjnych. Głównym celem badawczym jest eksploracja organizacyjnych celów tych organizacji oraz rekonstrukcja na tej podstawie dążeń i wartości zmierzająca do ich opisu jako wspólnoty celu. Opierając się na dokumentach prawnych, dokonano analizy zawartości statutów organizacji pozarządowych będących organizacjami kooperacyjnymi. Na podstawie wyników można mówić o homogeniczności wartości organizacji kooperacyjnych i wartości sektora organizacji pozarządowych. Wyniki posłużyć mogą jako podstawa do dalszej eksploracji fenomenów organizacyjnych występujących w organizacjach kooperacyjnych.

Słowa kluczowe: organizacje kooperacyjne, wartości, cele organizacyjne, wspólnota celu 


\section{Wstęp}

W dobie dynamicznego rozwoju nowych technologii zasadne zdaje się ponowne zastanowienie nad znaczeniem pojęcia ,społeczność” (ang. community). Termin ten analizują między innymi badacze zajmujący się ekonomią współdzielenia (ang. sharing economy), wskazując na praktykę wspólnego uczestnictwa grupy ludzi w aktywnościach angażujących zasoby, co do których użytkownicy nie posiadają zazwyczaj prawa własności [Richardson, 2015: 122]. Termin „społeczność” nie tylko opisuje zbiorowości osób połączonych ze sobą przez więzi społeczne, ale raczej odwołuje się do wspólnoty celu jednoczącej zorientowanych wokół siebie ludzi [Grabher, Ibert, 2014: 99]. Wspólnota celu rozumiana jest tu jako praca wykonywana wspólnie dla osiągnięcia zamierzonego rezultatu [Kramarz, 2016: 236].

Ostatnimi laty obserwujemy rosnące zainteresowanie podejmowaniem pracy w nowych formach (ang. new ways of working). Zjawisko to obejmuje zarówno zwiększającą się popularność biur coworkingowych [Hirst, 2011: 767], jak i wykorzystywanie domów jako miejsc pracy [Sewell, Taskin, 2015: 1508], tworzenie tak zwanych gorących biurek (ang. hot desk) [Bosch-Sijtsema i inni, 2010: 183] i wirtualny nomadyzm [Chen, Nath, 2005: 58]. Formą pracy zbliżoną do coworkingu jest praca w otwartych zakładach wytwórczych nazywanych organizacjami kooperacyjnymi (ang. collaborative spaces, collaborative communities), znanych również pod nazwami hackerspace, makerspace i fab lab. Wiele z tych organizacji, opisując swoją działalność, korzysta z terminu „społeczność”. Hackerspace Trójmiasto pisze o sobie tak:

W Hackerspace nabywamy i poszerzamy swoją wiedzę. Dzięki społeczności, którą budujemy, czas na naukę nowego zagadnienia znacząco się skraca. To miejsce, w którym dzielimy się ze sobą wiedzą, czerpiąc z wielości specjalizacji naszych członków. W Hackerspace można znaleźć współpracowników do realizacji projektów i mentorów',

a Makerspace Zakład z Poznania tak:

Jesteśmy społecznikami, fachowcami z różnych dziedzin i działamy dla społeczności wytwórców. Tworzymy oddolną inicjatywę, do której zapraszamy wszystkich zainteresowanych ideą Makerspace (...). Zakład to przede wszystkim ludzie. Nie narzucamy temu miejscu sztywnej formy. To, jak Zakład funkcjonuje, zależy od nas wszystkich ${ }^{2}$.

Odwołanie do społeczności pojawia się również w dyskursie naukowym dotyczącym organizacji kooperacyjnych. Fleischmann, Hielscher i Merritt [2016: 117], opisując tę ideę, piszą o wspólnotowych, opartych na społeczności warsztatach

${ }^{1}$ Stowarzyszenie Hackerspace Trójmiasto, www.hs3.pl [dostęp: 18.04.2018].

${ }^{2}$ Makerspace Zakład, www.zaklad.org [dostęp:18.04.2018]. 
wytwórczych wspierających proces współtworzenia, a Wolf, Troxler, Kocher, Harboe i Gaudenz [2014: 1] definiują ją zwięźle jako społeczność wytwórców.

\section{Organizacje kooperacyjne}

Organizacje kooperacyjne to pracownie służące pracy konstrukcyjnej. Pojawiły się one w Polsce razem z ruchem społecznym wytwórców (makerów). Jego pojawienie się interpretowane jest jako skutek zwiększającego się znaczenia kilku społeczno-kulturowych nurtów, w tym głównie „,zrób-to-sam” (DIY) oraz ruchu otwartego oprogramowania [Peppier, Bender, 2013: 23]. Obecnie organizacji tych jest ponad tysiąc [Schmidt, Brinks, 2017: 1]. W Polsce, według danych krajowego rejestru sądowego, aktywnie działają dwadzieścia dwie: sześć makerspace'ów, dziewięć fab labów i siedem hackerspace'ów.

Grabher i Ibert, zgłębiając charakter organizacji kooperacyjnych, uznali, że tym, co najlepiej je charakteryzuje, są demokratyzacja dostępu do technologii, wszechstronność i wspólnotowość [Grabher, Ibert, 2014: 103]. Demokratyzacja dostępu do technologii przejawia się przede wszystkim w tym, że z pracowni może korzystać każdy zainteresowany. Oznacza to również, że nie istnieją kryteria przyjęcia, a zaangażowana społeczność dysponuje zróżnicowanymi kompetencjami w rozumieniu zarówno ich treści, jak i poziomu. Wszechstronność jest efektem tego, że pracownie wyposażone są nie tylko w zaawansowane elektronicznie urządzenia (drukarki 3D, plotery laserowe i inne), lecz także w narzędzia związane z tradycyjnymi rzemiosłami (jak tokarki czy krosna). W zasadzie nie można określić produktu końcowego, który powstaje w pracowni - może to być odzież, mebel, oprogramowanie komputerowe. Ponieważ pracownie są miejscem pracy osób wielu profesji, można też w ich wypadku mówić o wspólnotowości. Spotykają się tam amatorzy i profesjonaliści, artyści i inżynierowie, programiści i rzemieślnicy. Pozwala to twierdzić, że organizacje kooperacyjne są potencjalnymi przestrzeniami współpracy ludzi o różnych tożsamościach zawodowych.

O ile rozmaite formy organizacji kooperacyjnych łączą wspomniane cechy, każda z nich ma też swoją historię i płynące z niej unikalne wartości.

Twórcą pierwszych fab labów był Massachusetts Institute of Technology, co współcześnie odzwierciedla się między innymi w zestawie warunków stawianych przed organizacjami chcącymi przyjąć tę nazwę. Ich spis zawiera się w wewnętrznych dokumentach specyfikujących wymagania technologiczne, odnoszących się do przestrzeni roboczej wykorzystywanej w fab labach oraz - bardziej ogólnie - w dokumencie The Fab Charter [Troxler, 2010: 16]. Celem działania fab labów definiowanym w The Fab Charter jest „tworzenie międzynarodowej sieci lokalnych laboratoriów, które umożliwiają tworzenie, rozwijanie i produkowanie wynalazków każdemu”’3. W Polsce organizacje tego typu najczęściej reje-

${ }^{3}$ Polskie thumaczenie The Fab Charter za: Fab Lab Lublin, www.fablabl.pl/misja/ [dostęp: 18.04.2018]. 
strowane są jako stowarzyszenia lub fundacje, jakkolwiek część funkcjonuje też w formie prywatnych inicjatyw.

Hackerspace'y są organizacjami promującymi kulturę i etykę hakerską. Ich często przywoływaną wykładnią są prace Stevena Levy'ego, który dokonał deskrypcji dążenia hakerów do wolności informacji, samodoskonalenia i dostępu do technologii, ich niechęci do hierarchii i merytokracji [Levy, 1984: 300-325]. Wszystkie siedem hackerspace'ów funkcjonujących w tej chwili w Polsce to organizacje pozarządowe.

Głównym celem działania makerspace'ów jest tworzenie indywidualnych projektów. Twórców zgromadzonych w tych organizacjach charakteryzuje samomotywacja i autonomiczność [Hippel, 2007: 294-300]. Często ich potrzebą adresowaną do reszty społeczności jest dostęp do informacji zwrotnej, pomoc w doskonaleniu własnych projektów i budowanie autorytetu wobec innych twórców [Franke i in., 2006: 315]. Głównym przedmiotem ich zainteresowania są projekty wykorzystujące kompetencje związane z tradycjami rzemieślniczymi - stolarstwem, szkutnictwem, ślusarstwem i innymi. Większość organizacji tego typu w Polsce przyjmuje formę stowarzyszeń lub fundacji, jakkolwiek są pośród nich również prywatne działalności gospodarcze.

Podczas gdy organizacje kooperacyjne rozpoznawalne są w Polsce przez praktyków biznesu i trzeciego sektora, świat akademicki nie wypracował dotychczas ich opisu naukowego. Niemal wszystkie badania poświęcone laboratoriom wytwórczym realizowane są poza Polską [Shank, 2006; Hua i in., 2010; Halverson, Sheridan, 2014; Lindtner, 2014; Rosner, Fox, 2016]. Wyjątek stanowią badania nad kolektywami hakerskimi [Zaród, 2017: 1-28]. Dlatego też w niniejszym artykule podjęto się pierwszej próby analizy społeczności wytwórców w Polsce.

\section{Metodyka badań}

Ramę teoretyczną analizowanych zagadnień stanowi jakościowa analiza zawartości aktów prawnych - statutów organizacji pozarządowych będących inicjatorami działania makerspace'ów, fab lab’ów i hackerspace'ów. Analiza zawartości to technika, której celem jest badanie jawnej części eksplorowanego dokumentu [Grabowski, 2013: 79]. Lącznie do badania wykorzystano siedemnaście statutów stowarzyszeń i fundacji założycielskich. Liczba ta odpowiada około $80 \%$ wszystkich organizacji tego typu w Polsce. Badanie miało na celu rekonstrukcję wartości przyświecających organizacjom kooperacyjnym, ugruntowanych w statutowo założonych celach organizacji i sposobach ich realizacji, a także wpisanie ich w kontekst ustawy o działalności pożytku publicznego i o wolontariacie $^{4}$ jako dokumentu istotnego dla całego środowiska działaczy trzeciego sektora. Po pierwsze autorkę interesowało istnienie wątków tematycznych w ramach

${ }^{4}$ Ustawa z dnia 24 kwietnia 2003 r. o działalności pożytku publicznego i o wolontariacie (Dz.U. 2003, nr 96. poz. 873). 
analizowanej problematyki - podjęto się więc analizy dominujących w statutach celów, po to by zrekonstruować obecne w nich rozumienie społeczności jako wspólnoty celu. Po drugie skoncentrowano się na identyfikacji tych wątków, których pojawienie się w statucie było efektem wzorowania się na wspomnianych nadrzędnych dokumentach. Owo wzorowanie się traktowano jako próbę instytucjonalizacji wartości i norm istotnych dla badanych społeczności [Blau, 1962]. I po trzecie zamierzano zidentyfikować te zapisy, które odróżniają makerspace'y, fab lab'y i hackerspace'y od siebie, oraz te, które występują w statutach wszystkich typów organizacji, aby uchwycić te obszary ich funkcjonowania, które mogą świadczyć o obrazie społeczności twórców i każdej poszczególnej formy organizacji kooperacyjnej z osobna. Próba ta miała na celu uchwycenie niuansów różnicujących tę społeczność.

Selekcja materiałów dokonana była na podstawie doboru celowego - wybrano statuty tych organizacji kooperacyjnych, których formą prawną jest stowarzyszenie lub fundacja. Pozostałe bowiem, jako prywatne firmy, nie mają obowiązku sporządzania podobnych dokumentów. Spośród dwudziestu dwóch zidentyfikowanych organizacji kooperacyjnych siedemnaście to organizacje pozarządowe, a pięć inicjatywy prywatne. Dobór kolejnych analizowanych celów miał charakter teoretyczny i polegał na ciągłym porównywaniu. Rozstrzygnięcia, jakiego rodzaju kategorie porównywać, dokonywane były na bieżąco, w trakcie kodowania i analizy materiału [Strauss, Corbin, 1990: 177]. Bazując na metodzie ciągłego porównywania, starano się dobierać próby zarówno podobne do siebie, jak i bardzo różne. Celem podjętych analiz było uchwycenie jak największej liczby zróżnicowań oraz wzajemnych powiązań [Charmaz, 2009: 74]. Dlatego też podstawą doboru kolejnych celów nie były odgórnie ustalone założenia, ale bieżące decyzje analityczne [Glaser, Strauss, 1967: 45].

\section{Wartości pośredniczące w transakcjach społecznych}

Rozpoznane kategorie analizowano, wykorzystując punkt odniesienia socjologicznej teorii działania społecznego w ujęciu Talcotta Parsonsa, a konkretnie jego rozróżnienie wartości pośredniczących w transakcjach społecznych na wartości uniwersalistyczne i partykularystyczne.

Za przyjętym kryterium analizy stoi założenie, że „wartość jest tym, co sprawia, że dana rzecz wywołuje zainteresowanie sobą. Zainteresowanie rodzi skierowane ku przyszłości dążenie do realizacji tego, co nie zostało jeszcze osiągnięte" [Perry, 1926: 250]. Przesłanie zawarte w teorii wartości Perry’ego zdają się potwierdzać również inni akademicy. Chociażby Roman Ingarden tak pisał o wartościach: „Wartość to stan rzeczy czy przedmiot, który wzbudza emocje pozytywne i ku któremu jednostka skierowuje swe pragnienia i dążenia" [Ingarden, 1966: 64]. Dlatego właśnie cele odnalezione w statutach przeanalizowano w świetle wartości.

Talcott Parsons uważał, że jednymi z determinantów orientacji aktorów i ich wyborów są wartości [Parsons, 1972: 279-284]. Wartości uniwersalistyczne to 
jego zdaniem takie, których uznanie nie jest zależne od statusu uznającego. W badaniu porównane zostały z ideami przyświecającymi autorom ustawy o działalności pożytku publicznego i wolontariacie definiującej zadania z zakresu sfery publicznej, których realizowanie jest od organizacji oczekiwane. Można powiedzieć, że pojawienie się (lub brak) zapisów zbieżnych z ustawą w analizowanych statutach wynika z wpisywania się organizacji kooperacyjnych w nurt działalności charakterystycznej dla całego środowiska działaczy trzeciego sektora, a nie tylko innych organizacji kooperacyjnych. Wartości partykularystyczne to natomiast takie, których uznanie zależy od statusu uznającego. W przypadku tego badania wyrażały się one w tych celach, które symbolizują ideały wytwórców i nawiązują do procesu wytwórczego. Ich pojawienie się w statutach to przejaw cenienia sobie tych wartości, które odpowiadają charakterowi ruchu społecznego stojącego za organizacją.

\section{Wyniki badań empirycznych}

Badanie zaowocowało wypracowaniem dwóch zestawów wartości wynikających wprost $\mathrm{z}$ celów statutowych analizowanych organizacji. Jako pierwsze omówione zostaną wartości uniwersalistyczne przedstawione na rys. 1. Jak już sygnalizowano, analizowano je przez porównanie z ustawą o działalności pożytku publicznego i o wolontariacie, zakładając, że uczynienie w swoich statutach zapisów zbieżnych z ustawą jest przejawem chęci społecznej integracji społeczności wytwórców ze środowiskiem działaczy pozarządowych.

W sferze wartości uniwersalistycznych zauważalna jest największa jednorodność całej społeczności wytwórców. Wartości istotnych dla wszystkich typów organizacji jest tu więcej niż w przypadku wartości partykularystycznych. Zauważalne są również pewne wątki tematyczne w odniesieniu do poszczególnych społeczności.

Osoby zaangażowane w działalność makerspace'ów zdają się koncentrować na celach zorientowanych na integrację - pojawia się docenianie integracji kulturowej i międzypokoleniowej oraz ochrona mniejszości narodowych. Przykładami takich celów są: „tworzenie programów społeczno-edukacyjnych, służących reintegracji społecznej, wyrównywaniu szans, promocji kultury, współpracy międzynarodowej i ekologii”s (Makerspace Zakład) czy „kształtowanie postaw odpowiedzialności obywatelskiej, otwartości na inne kultury, wzajemnego szacunku, tolerancji, sprawiedliwości społecznej i zaangażowania na rzecz dobra wspólnego" 6 (Makerspace Zielona Góra).

Innym zauważalnym wątkiem są cele zorientowane na doskonalenie się społeczności twórców - docenianie talentu i rozwoju osobistego. Cele te łączą społeczności związane z makerspace’ami i fab labami. Przykładem zapisu z tego obszaru

5 Statut fundacji Animatornia z dnia 5 lipca 2013 r.: www.animatornia.org [dostęp: 18.04.2018].

${ }^{6}$ Statut fundacji Fabryka Pasji z dnia 4 lutego 2015 r.: www.fabrykapasji.org [dostęp: 18.04.2018]. 


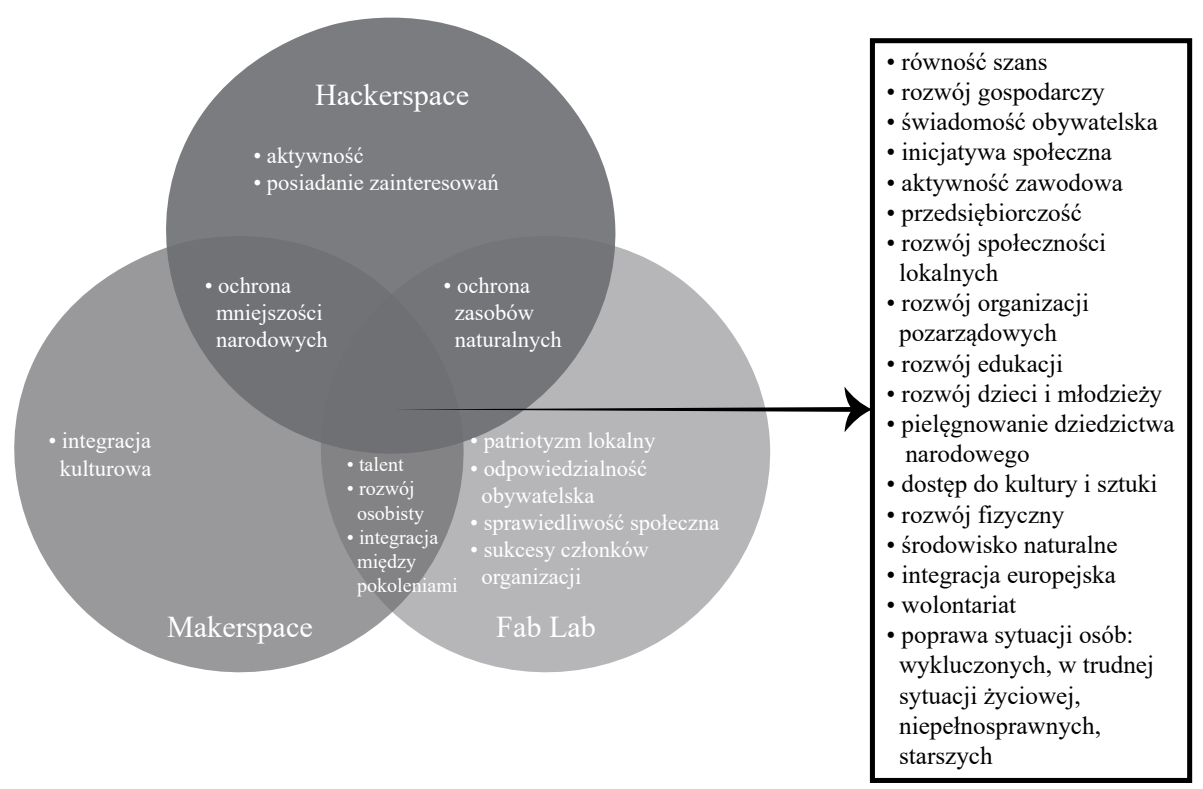

Rys. 1. Wartości uniwersalistyczne organizacji kooperacyjnych w Polsce

Źródło: opracowanie własne.

jest ,,podnoszenie kompetencji w korzystaniu z cyfrowych technologii”", znajdujący się w statucie fundacji Fab Lab Trójmiasto. Tym jednak, co zdaje się odróżniać środowiska związane z fab labami od reszty, jest silny akcent położony na rozwój społeczeństwa obywatelskiego i społeczności lokalnych. Tylko w tych statutach pojawiają się takie cele jak ,działalność na rzecz tworzenia i rozwoju społeczeństwa obywatelskiego"8 (Fab Lab Freelab). Kwestią podnoszoną przez statuty analizowanych fab labów jest też odpowiedzialność w wymiarze ekologicznym; to jedna z cech łączących te społeczności ze społecznościami hakerskimi. Cele takie jak ,„propagowanie ekologicznego stylu życia oraz świadomego i odpowiedzialnego korzystania z zasobów"9 pojawiają się w statutach organizacji obu typów. Tym, co wyróżnia hackerspace’y spośród innych organizacji kooperacyjnych, jest docenianie aktywności oraz realizowanie posiadanych pasji. Wartość tę urzeczywistniają na przykład przez ,udostępnianie przestrzeni, środków i wiedzy do

7 Statut fundacji Fab Lab Trójmiasto z dnia 4 lipca 2013 r.: www.fablabt.org [dostęp: 18.04.2018].

${ }^{8}$ Statut Stowarzyszenia Freelab z dnia 25 czerwca 2016 r.: www.wrzesnia.freelab.edu.pl [dostęp: 18.04.2018].

9 Statut fundacji Makerspace Lublin z dnia 30 kwietnia 2014 r.: www.archive.li [dostęp: 18.04.2018]. 
realizacji projektów i zainteresowań"10 (Hackerspace Lublin). Za niezwykle ciekawą autorka uważa w tym kontekście dychotomię między docenianiem talentu przez środowiska związane $\mathrm{z}$ fab labami i makerspace'ami a hakerskim uznaniem za wartość aktywności samej w sobie. Przekaz ten należy odczytywać jako przedkładanie wartości tkwiącej w procesie osiągania doskonałości ponad samą doskonałość.

Wartości wspólne dla całego środowiska twórców przedstawiają szeroką gamę zadań z zakresu sfery publicznej wyniesionych z ustawy o organizacjach pożytku publicznego i o wolontariacie. Widać tam wyraźnie, w jakich obszarach organizacje kooperacyjne upatrują ogniwa zacieśniania integracji swojej społeczności z innymi działaczami sfery pozarządowej. W skrócie można sprowadzić te obszary do czterech kategorii tematycznych: (1) gospodarczej (wyrażanej w takich wartościach jak przedsiębiorczość, aktywność zawodowa, czy wreszcie rozwój gospodarczy), (2) społecznej (świadomość obywatelska, inicjatywa społeczna, rozwój społeczności lokalnych, integracja europejska), (3) wspierania zadań publicznych (rozwój organizacji pozarządowych, wolontariat, rozwój fizyczny, środowisko naturalne, rozwój edukacji, pielęgnowanie dziedzictwa narodowego, dostęp do kultury i sztuki) oraz (4) wspierania obywateli (równość szans, poprawa sytuacji osób wykluczonych, w trudnej sytuacji życiowej, niepełnosprawnych, starszych, rozwój dzieci i młodzieży).

Nie mniej interesujące jest jednak to, czego zabrakło w analizowanych dokumentach. $Z$ bogatej listy zadań adresowanych do organizacji pozarządowych za pośrednictwem ustawy wybrać można te, które nie pojawiły się w żadnym statucie. Ilustrują one takie wartości jak świadomość prawna społeczeństwa, równouprawnienie kobiet i mężczyzn, bezpieczeństwo publiczne, obronność państwa, rozwój demokracji, swoboda obywatelska, pomoc ofiarom katastrof i działań wojennych, ochrona praw konsumentów, wspieranie Polaków za granicą, kombatantów, osób represjonowanych i weteranów oraz promocja Rzeczypospolitej Polskiej za granicą. Wymienione wartości zdają się wpisywać w nurt działań ponadlokalnych - zauważalne jest nawiązanie do obronności, promocji Polski czy wspieranie rodaków na emigracji. Z pewnością brak zbliżonych do tych wartości celów jest wytłumaczalny przez odwołanie do uprawnień wymaganych do działań z zakresu na przykład obrony terytorialnej lub kompetencji niezbędnych $\mathrm{w}$ poradnictwie prawnym. Mamy tu jednak do czynienia również z wartościami, których brak zdaje się zastanawiający. Równouprawnienie kobiet i mężczyzn jest wartością pojawiającą się nie tylko w ustawie o organizacjach pożytku publicznego i o wolontariacie, ale również w tekstach opisujących etykę hakerską. Pomimo to żaden $\mathrm{z}$ hakerspace'ów nie zdecydował się na umieszczenie adekwatnych do równości zapisów w swoim dokumencie założycielskim. Innym przykładem jest swoboda obywatelska, często stereotypowo utożsamiana z kulturą hakerską, która również nie pojawia się w żadnym statucie. I w końcu wielokrotne nawiązywanie do integracji kulturowej czy ochrony mniejszości narodowych i etnicznych,

${ }^{10}$ Statut fundacji Makerspace Lublin z dnia 30 kwietnia 2014 r.: www.archive.li [dostęp: 18.04.2018]. 
pojawiające się niemal we wszystkich statutach, okazuje się nie współistnieć ze wspieraniem rodaków przebywających na emigracji, stanowiących tam mniejszości narodowe lub etniczne.

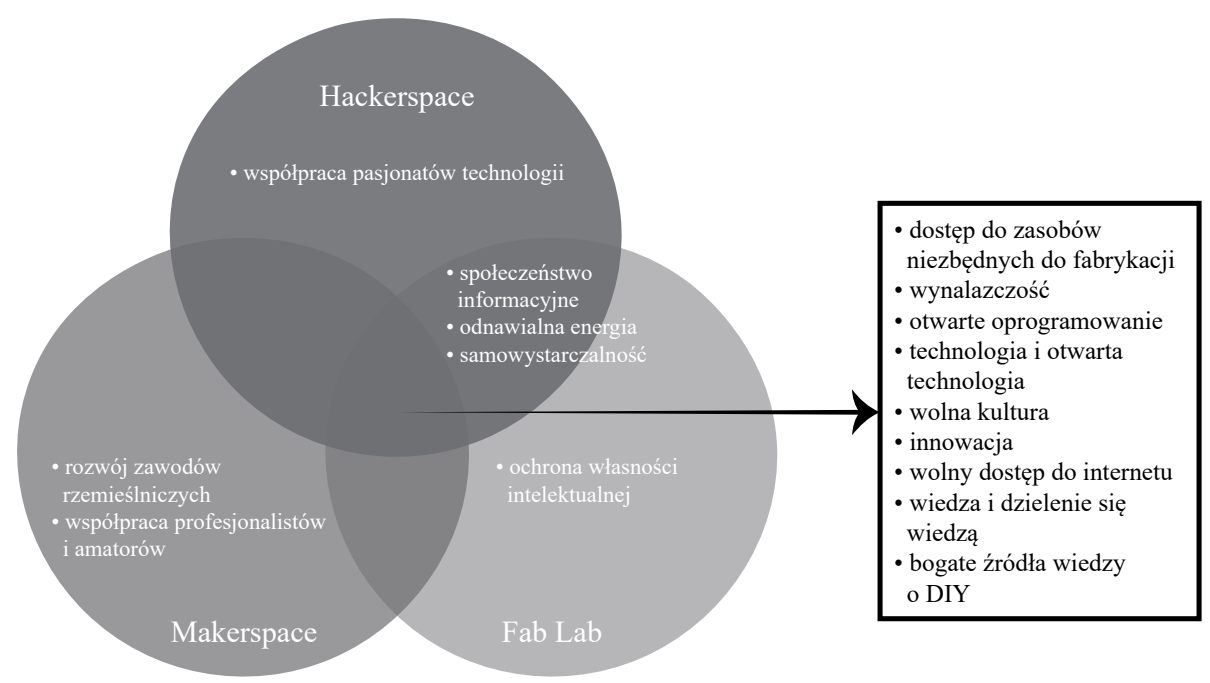

Rys. 2. Wartości partykularystyczne organizacji kooperacyjnych w Polsce

Źródło: opracowanie własne.

W przypadku wartości partykularystycznych (przedstawionych na rys. 2) zauważalna staje się malejąca homogeniczność systemów wartości społeczności wytwórców. Celów tożsamych dla wszystkich typów organizacji jest coraz mniej. Rośnie natomiast liczba tych, które różnicują je między sobą. Widoczne stają się także odwołania do historycznie kształtowanej tożsamości twórców zrzeszonych w różnych organizacjach. Zauważalne jest to chociażby w dążeniach społeczności makerspace'ów do promocji i wspierania zawodów rzemieślniczych. Makerspace Chorzów realizuje to przez ,inicjowanie, organizowanie i wspieranie działalności w zakresie kultury, sztuki, ochrony dóbr kultury i tradycji, a w szczególności w zakresie rozpowszechniania zawodów rzemieślniczych, w tym szkutnika i stolarza" ${ }^{11}$. Podkreślana jest też rola współpracy profesjonalistów i amatorów, co sygnalizuje, że społeczność ceni zarówno kompetencje profesjonalne, jak i niepoparte wiedzą, często intuicyjne działanie. Obrazuje to „wspieranie i integracja młodych twórców: profesjonalistów i amatorów"12 opisane w statucie Makerspace'u Zakład.

${ }^{11}$ Odpis aktualny Krajowego Rejestru Sądowego Fundacji Bobrowe Żeremia zarejestrowanej dnia 30 stycznia 2017 r., www.ems.ms.gov.pl. [dostęp: 18.04.2018].

${ }_{12}$ Statut fundacji Animatornia $\mathrm{z}$ dnia 5 lipca 2013 r., www.animatornia.org [dostęp: 18.04.2018]. 
Jak już wcześniej wskazano. hakerzy zdają się za wartość upatrywać aktywność per se. Jest to też widoczne w analizie ich partykularystycznych wartości ceniona jest współpraca hobbystów technologii, bez odwołania do stopnia ich profesjonalizacji. „Skupianie pasjonatów różnych dziedzin technicznych chętnych do wspólnego poszerzania wiedzy oraz dzielenia się doświadczeniem"13 to cel przyświecający między innymi społeczności Hackerspace’u Kraków.

Tym, co charakterystyczne dla fab labów, jest ochrona własności intelektualnej, widoczna w takich celach statutowych jak ,zgłaszanie wniosków mających na celu ochronę własności intelektualnej"14 (Freelab). Zatem uzasadnione jest wnioskowanie, że stawia to fab laby niejako w opozycji do pozostałych organizacji kooperacyjnych, które opowiadają się za wolnym dostępem do oprogramowania i otwartą technologią, choć to tylko częściowo trafny wniosek - szczególnie, że zapisy o wolnym oprogramowaniu znajdują się również w treściach statutów samych fab labów. Ta pozorna sprzeczność wiąże się z zapisami The Fab Charter, które jasno odnoszą się do statusu innowacji wypracowanych w laboratoriach. Wynika z nich, że innowacje te mogą zostać objęte patentem, jeśli osoba za nie odpowiedzialna życzy sobie tego. Jednocześnie wskazane jest, aby dokumentacja techniczna związana z projektem pozostała do dyspozycji pozostałych twórców, by mogli czerpać $z$ niej wiedzę i inspirację.

Ten potencjalny transfer wiedzy, jak już zasygnalizowano, wiąże się ze zbiorem wartości tożsamych dla wszystkich organizacji i zawierającym w sobie nawiązania do otwartego oprogramowania i otwartej technologii, a także ubogacania źródeł wiedzy o DIY czy - po prostu - dzielenia się wiedzą (z zakresu szeroko rozumianych technologii). Słowo „wiedza” i jego odmiany pojawia się w statutach blisko pięćdziesiąt razy i często konotuje z pozostałymi wartościami ze wspomnianego zbioru. „Upowszechnianie kultury wolnego oprogramowania i wolnej wiedzy”15 to cel między innymi Hackerspace'u Kraków. Wyraźne jest także dążenie do tego, by proces dzielenia się wiedzą angażował również społeczność lokalną, na przykład przez „współdziałanie z jednostkami samorządu terytorialnego w opracowaniu i realizacji programów i planów działania zmierzających do poprawy stanu wiedzy z zakresu technologii szybkiego prototypowania i nauk powiązanych"16 (Freelab). Inny trend, upatrywanie w wiedzy spoiwa postaw obywatelskich, zobrazowany jest między innymi w statucie Fab Labu Łódź: ,,upowszechnianie idei opartego na wiedzy społeczeństwa informacyjnego i informatycznego, korzystającego z osiągnięć technicznych w dziedzinie automatyki i robotyki”"17.

${ }^{13}$ Statut fundacji Hackerspace Kraków z dnia 1 października 2012 r., www.wiki.hackerspace-krk.pl [dostęp: 18.04.2018].

14 Statut Stowarzyszenia Freelab z dnia 25 czerwca 2016 r., www.wrzesnia.freelab.edu.pl [dostęp: 18.04.2018].

15 Statut fundacji Hackerspace Kraków z dnia 1 października 2012 r., www.wiki.hackerspace-krk.pl [dostęp: 18.04.2018].

${ }_{16}$ Statut Stowarzyszenia Freelab z dnia 25 czerwca 2016 r., www.wrzesnia.freelab.edu.pl [dostęp: 18.04.2018].

${ }_{17}$ Statut Fundacji FabLab Łódź z dnia 15 grudnia 2008 r., www.fablablodz.org [dostęp: 18.04.2018]. 
Kolejną bliską znaczeniem kategorią wartości pojawiającą się w statutach zarówno fab labów, jak i hackerspace'ów oraz makerspace'ów jest kategoria składająca się z innowacji i wynalazczości. Wartości te często występują w statuach w kontekście wpływu na lokalną politykę oświatową, tak jak w statucie Fab Labu Łódź: „wdrażanie nowych, innowacyjnych form nauczania i oceniania cechujących się wyższą skutecznością niż formy tradycyjne, wspieranie aktywnych metod nauczania, tworzenie programów edukacyjnych"18, czy równie często wymieniany obok wynalazczości taki cel jak ,wspieranie rozwoju techniki, wynalazczości i innowacyjności oraz rozpowszechnianie i wdrażanie nowych rozwiązań technicznych"19, występujący w statucie Hackerspace Lublin. Wynalazczość i innowacyjność tłumaczone są często przez organizacje kooperacyjne przez odwołanie do technologii, co ilustruje cel „tworzenia miejsc spotkań wszelkich podmiotów i obywateli związanych z nowymi technologiami i innowacyjnymi rozwiązaniami" ${ }^{20}$ (Hackerspace Białystok). Ostatnią wspólną dla całego środowiska wartością jest dostęp do zasobów niezbędnych do fabrykacji. Fab Lab Kielce stara się realizować tę wartość przez ,pomoc swoim członkom oraz sympatykom w budowie urządzeń elektrycznych, elektronicznych i mechanicznych zarówno w zakresie dostępu do wiedzy, jak i maszyn, urządzeń, narzędzi oraz niezbędnych części”"21. Widać dzięki temu, że pojęcie ,zasoby” jest przez wytwórców rozumiane szeroko - w znaczeniu zasobów nie tylko materialnych, ale również niematerialnych.

\section{Podsumowanie}

Tekst ten stanowi próbę deskrypcji środowisk wytwórców przez rekonstrukcję ich organizacyjnych celów i wartości. Okazuje się, że tożsamość organizacji kooperacyjnych jest silnie związana $\mathrm{z}$ działalnością pożytku publicznego. Jest to z pewnością uwarunkowane formalną przynależnością do środowisk organizacji pozarządowych, jakkolwiek argument ten nie tłumaczy tak wysokiej zbieżności celów organizacji kooperacyjnych z zadaniami publicznymi definiowanymi przez ustawodawstwo. Treści analizowanych statutów świadczą o tym, że przedstawiciele makerspace'ów, hackerspace'ów i fab labów starają się włączać w główne nurty działania trzeciego sektora zarówno w wymiarze tych zadań, które intuicyjnie można by było połączyć z ruchem wytwórców, jak i innych. Wartości organizacji kooperacyjnych odpowiadają potencjalnym potrzebom

18 Statut Fundacji FabLab Łódź z dnia 15 grudnia 2008 r., www.fablablodz.org [dostęp: 18.04.2018].

${ }_{19}$ Statut fundacji Makerspace Lublin z dnia 30 kwietnia 2014 r., www.archive.li [dostęp: 18.04.2018].

${ }^{20}$ Odpis aktualny Krajowego Rejestru Sądowego Fundacji Hacklag zarejestrowanej dnia 8 marca 2016 r., www.ems.ms.gov.pl [dostęp: 18.04.2018].

${ }^{21}$ Odpis aktualny Krajowego Rejestru Sądowego Stowarzyszenia FabLab Kielce Stowarzyszenie naukowo-techniczne zarejestrowanego dnia 4 listopada 2013 r., www.ems.ms.gov.pl [dostęp: 18.04.2018]. 
społeczności lokalnych, pojedynczych obywateli oraz - co oczywiste - zrzeszonych weń twórców.

Najczęściej pojawiającą się w statutach wartością jest wiedza. Zdaje się ona nie tylko przedmiotem dążeń makerów, ale też środkiem do osiągania różnorakich celów. Spaja ze sobą zarówno wartości partykularystyczne organizacji kooperacyjnych, jak i te, które są konstytutywnie powiązane z działalnością pożytku publicznego. Jest więc pomostem łączącym twórców i działaczy pozarządowych, a także instrumentem solidarności wewnątrz samego ruchu. $Z$ jednej strony rozszerza zasięg transakcji społecznej poza granice bezpośredniej interakcji, a z drugiej - wymiana tejże wiedzy wymaga interakcji.

Makerspace'y, fab laby i hackerspace'y analizuje się często łącznie jako organizacje kooperacyjne o podobnym sposobie funkcjonowania. Analiza ich wartości wykazała jednak cechy, które znacząco odróżniają je od siebie, stawiając pod znakiem zapytania zasadność zbiorczych opisów. Wszystkie formy organizacji kooperacyjnych współdzielą dążenie do szerzenia idei wolności, innowacyjności, wynalazczości i sprawczości twórczej, mijają się zaś na drodze do realizacji tych dążeń.

W realizacji badań wykorzystano technikę analizy zawartości. Służy ona badaniu jawnej części dokumentów. Analizowanie przy jej pomocy wartości zjawiska ulotnego i odczuwanego intuicyjnie - jest z pewnością ograniczeniem przedstawionej analizy. Należy jednak pamiętać, że stan badań na temat organizacji kooperacyjnych w Polsce jest mało zaawansowany. Problematyka ta jest ważna i aktualna. Z pewnością też wymaga bardziej szczegółowych analiz w kontekście efektów zarówno poznawczych, jak i aplikacyjnych. Badanie, którego konceptualne założenia przedstawiono w tym artykule, przyczynia się do wzbogacania wiedzy o makerspace'ach, fab labach i hackerspace'ach; może stanowić punkt wyjścia do przeprowadzenia analizy kultur organizacyjnych organizacji kooperacyjnych.

\section{Bibliografia}

Bosch-Sijtsema P., Ruhomäki V., Vartiainen M. (2010), Multi-location Knowledge Workers in the Office: Navigation, Disturbances and Effectiveness, „New Technology, Work and Employment", 25 (3).

Blau P. (1962), Operationalizing a Conceptual Scheme: The Universalism-Particularism Pattern Variable, „American Sociological Review”, 27 (2).

Charmaz K. (2009), Shifting the Grounds: Constructivist Grounded Theory Methods for the Twenty-First Century [w:] J. Morse, P. Stern, J. Corbin, B. Bowers, K. Charmaz, A. Clarke, Developing Grounded Theory: The Second Generation, Left Coast Press, Walnut Creek.

Chen L., Nath R. (2005), Nomadic Culture: Cultural Support for Working Anytime, Anywhere, „Information Systems Management”, 22 (4).

Fleischmann K., Hielscher S., Merritt T. (2016), Making Things in Fab Labs: A Case Study on Sustainability and Co-creation, „Digital Creativity”, 27 (2). 
Franke N., von Hippel E., Schreier M. (2006), Finding Commercially Attractive User Innovations: A Test of Lead User Theory, ,Journal of Product Innovation Management”, 23 (4).

Glaser B.G., Strauss A.L. (1967), The Discovery of Grounded Theory, Aldine, Chicago.

Grabowski H. (2013), Wykłady z metodologii badań empirycznych, Wydawnictwo Impuls, Kraków. Grabher G., Ibert O. (2014), Distance as Asset? Knowledge Collaboration in Hybrid Virtual Communities, „Journal of Economic Geography”, 14 (1).

Halverson E.R., Sheridan K.M. (2014), The Maker Movement in Education, „Harvard Educational Review", 84 (4).

Hippel E. von (2007), The Sources of Innovation, Oxford University Press, Oxford.

Hirst A. (2011), Settlers, Vagrants and Mutual Indifference: Unintended Consequences of HotDesking, ,Journal of Organizational Change Management”, 24 (6).

Hua Y., Loftness V., Kraut R., Powell K.M. (2010), Workplace Collaborative Space Layout Typology and Occupant Perception of Collaboration Environment, ,Environment and Planning B: Urban analytics and city science", 27 (3).

Ingarden R. (1966), Przeżycie, dzieło, wartość, Wydawnictwo Literackie, Kraków.

Kramarz M. (2016), Modele współdziałania w sieci-aktorzy i uwarunkowania, „Przedsiębiorczość i Zarządzanie", 7 (12).

Levy S. (1984), Hackers: Heroes of the Computer Revolution, Doubleday, New York.

Lindtner S. (2014), Hackerspaces and the Internet of Things in China: How Makers Are Reinventing Industrial Production, Innovation, and the Self, „China Information”, 2.

Odpis aktualny Krajowego Rejestru Sądowego fundacji Bobrowe Żeremia zarejestrowanej dnia 30 stycznia 2017 r., www.ems.ms.gov.pl [dostęp: 18.04.2018].

Odpis aktualny Krajowego Rejestru Sądowego fundacji Hacklag zarejestrowanej dnia 8 marca 2016 r., www.ems.ms.gov.pl [dostęp: 18.04.2018].

Odpis aktualny Krajowego Rejestru Sądowego stowarzyszenia FabLab Kielce stowarzyszenie naukowo-techniczne zarejestrowanego dnia 4 listopada 2013 r., www.ems.ms.gov.pl [dostęp: 18.04.2018].

Peppier K., Bender S. (2013), Maker Movement Spreads Innovation One Project at a Time, „Phi Delta Kappan”, 95 (3).

Perry R.B. (1926), General Theory of Value: Its Meaning and Basic. Principles Construed in Terms of Interest, Longmans Green, New York.

Parsons T. (1972), Szkice z teorii socjologicznej, tłum. A. Bentkowska, PWN, Warszawa.

Richardson L. (2015), Performing the Sharing Economy, „Geoforum”, 67.

Rosner D.K., Fox S.E. (2016), Legacies of Craft and the Centrality of Failure in a Mother-Operated Hackerspace, „New Media \& Society”, 18 (4).

Schmidt S., Brinks V. (2017), Open Creative Labs: Spatial Settings at the Intersection of Communities and Organizations, „Creative Innovation Management”, 26 (3).

Sewell G., Taskin L. (2015), Out of Sight, out of Mind in a New World of Work? Autonomy, Control, and Spatiotemporal Scaling in Telework, „Organization Studies”, 36 (11).

Shank M.J. (2006), Teacher Storytelling: A Means for Creating and Learning within a Collaborative Space, „Teaching and Teacher Education”, 22 (6).

Statut fundacji Animatornia z dnia 5 lipca 2013 r., www.animatornia.org [dostęp: 18.04.2018]. Statut fundacji Fab Lab Łódź z dnia 15 grudnia 2008 r., www.fablablodz.org [dostęp: 18.04.2018]. Statut fundacji Fab Lab Trójmiasto z dnia 4 lipca 2013 r., www.fablabt.org [dostęp: 18.04.2018]. Statut fundacji Fabryka Pasji z dnia 4 lutego 2015 r., www.fabrykapasji.org [dostęp: 18.04.2018]. 
Statut fundacji Hackerspace Kraków z dnia 1 października 2012 r., www.wiki.hackerspace-krk.pl [dostęp: 18.04.2018].

Statut fundacji Makerspace Lublin z dnia 30 kwietnia 2014 r., www.archive.li [dostęp: 18.04.2018].

Statut stowarzyszenia Freelab z dnia 25 czerwca 2016 r., www.wrzesnia.freelab.edu.pl [dostęp: 18.04.2018].

Strauss A., Corbin J. (1990), Basics of Qualitative Research: Grounded Theory Procedures and Techniques, Sage, Newbury Park.

Troxler P. (2010), Commons-Based Peer Production of Physical Goods: Is There Room for a Hybrid Innovation Ecology?, publikacja konferencyjna „Free culture research conference", Berlin.

Wolf P., Troxler P., Kocher P., Harboe J., Gaudenz U. (2014), Sharing is Sparing: Open Knowledge Sharing in Fab Labs, „Journal of Peer Production”, 5.

Zaród M. (2017), Hakerzy i kolektywy hakerskie w Polsce. Od operacjonalizacji do laboratoriów i stref wymiany, „Studia Socjologiczne”, 1 (224). 